
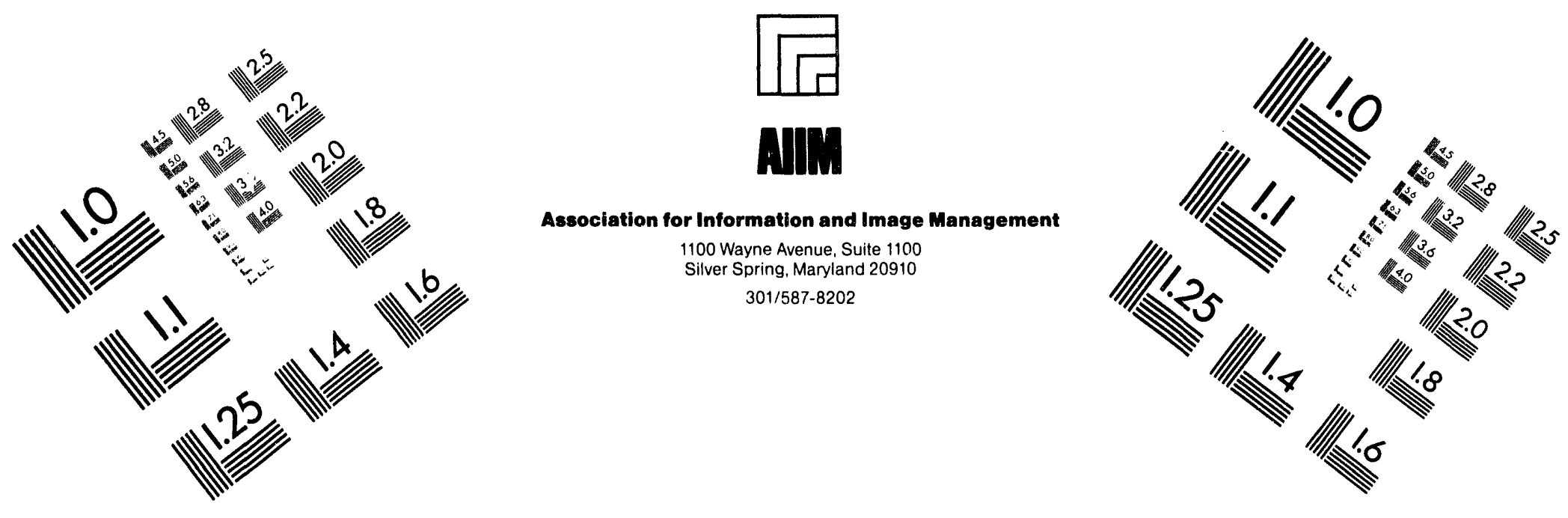

\title{
Centimeter
}

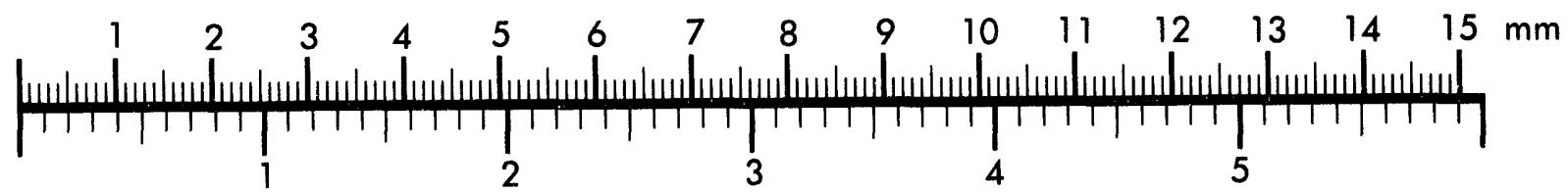
Inches
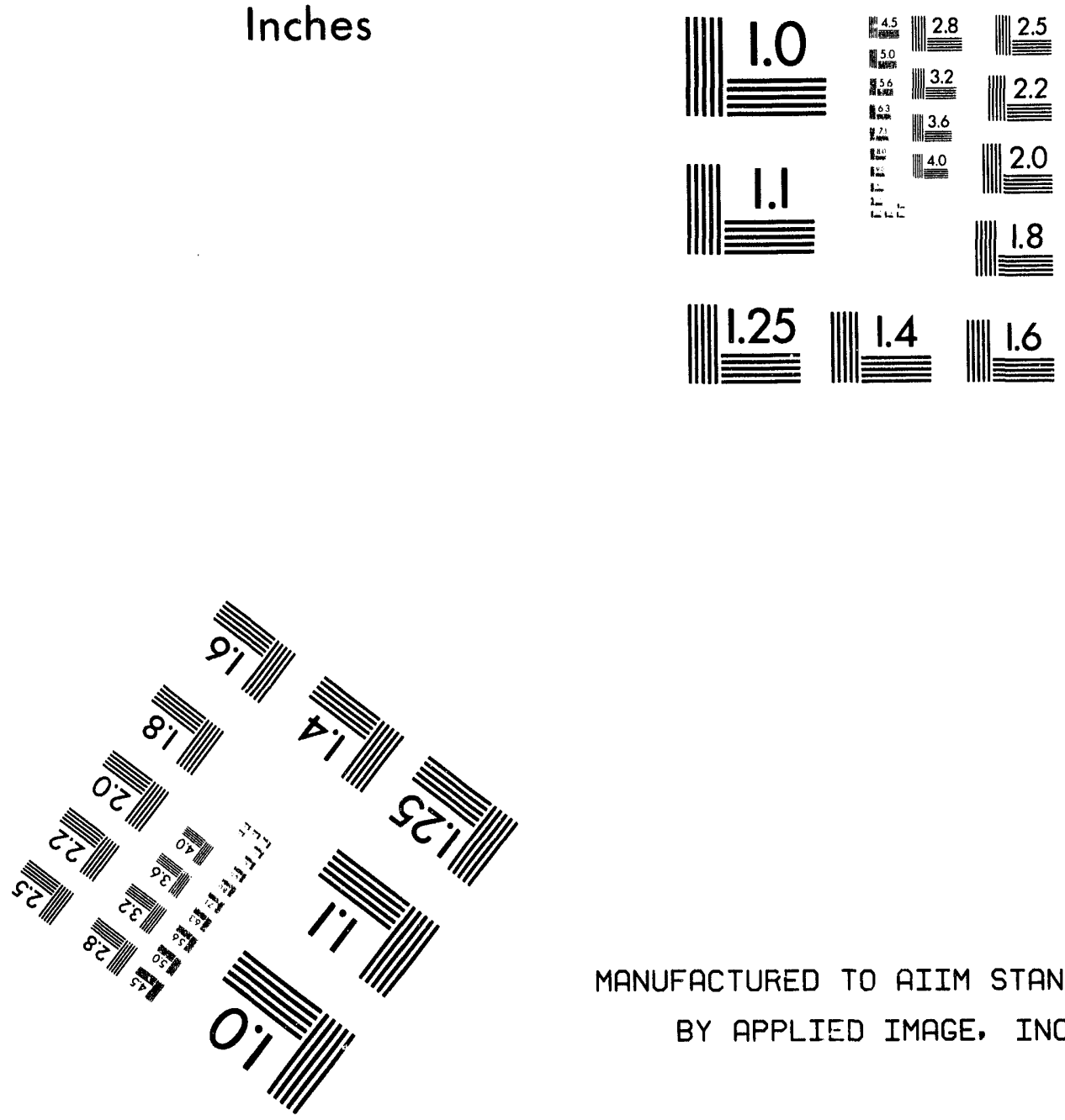

MANUFACTURED TO AIIM STANDARDS BY APPLIED IMAGE, INC.

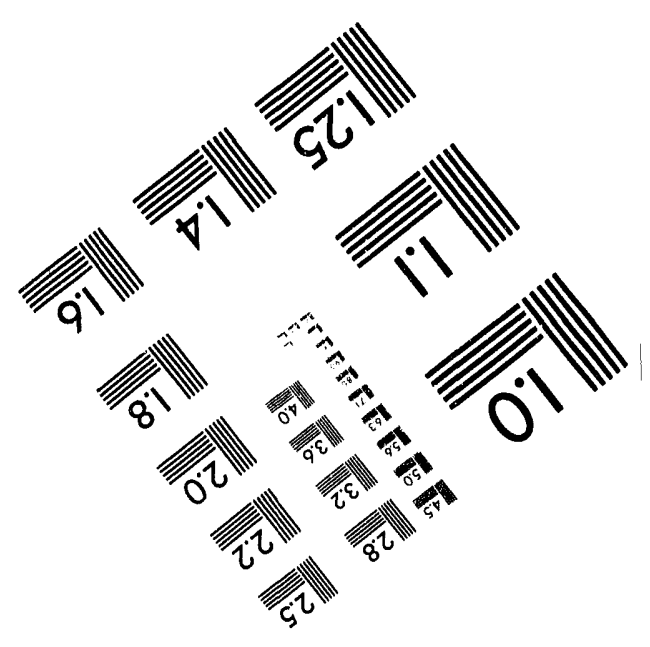



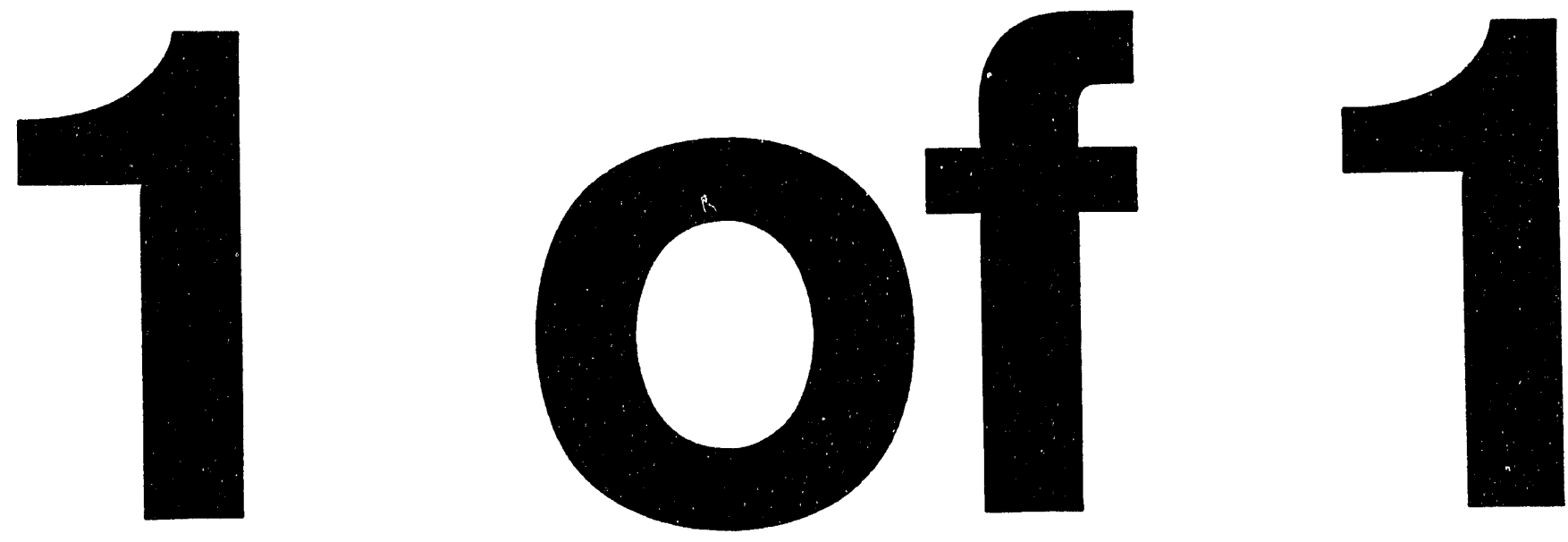
HANFORD ATOMIC PRODUCTS OPERATION - RICHLAND, WASHINGTON

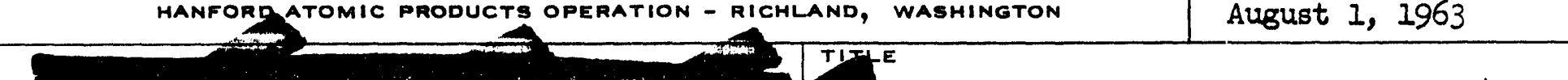

SERIES AND COPY NO.

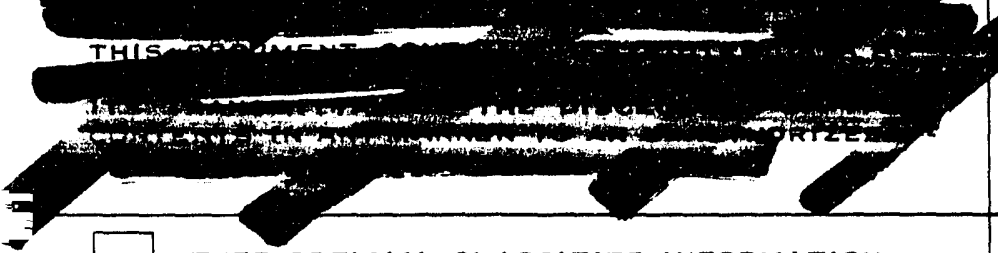

OTHER OFFICIAL CLABBIFIED INFORMATION THIS MATERIAL CONTAINB INFORMATION AFFECTING THE NATIONAL DEFENSE OF THE UNITED STATES WITHIN THE MEANING OF THE ESPIONAGE LAWB, TITLE 18, U. S.C., SECS, 793 AND 794, THE TRANSMISSION OR REVELATION OF WHICH IN ANY MANNER TO AN UNAUTHORIZED PERSON IS PROHIBITED BY L.AW.

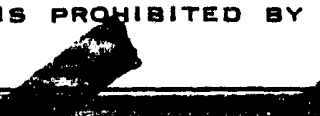

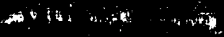
$+$ CERIM REPORT IV, PRODUCTION TEST IP-549-A EALF-PLANT LOW ALUM FEED WATER TREATIMENTI AT F REACTOR

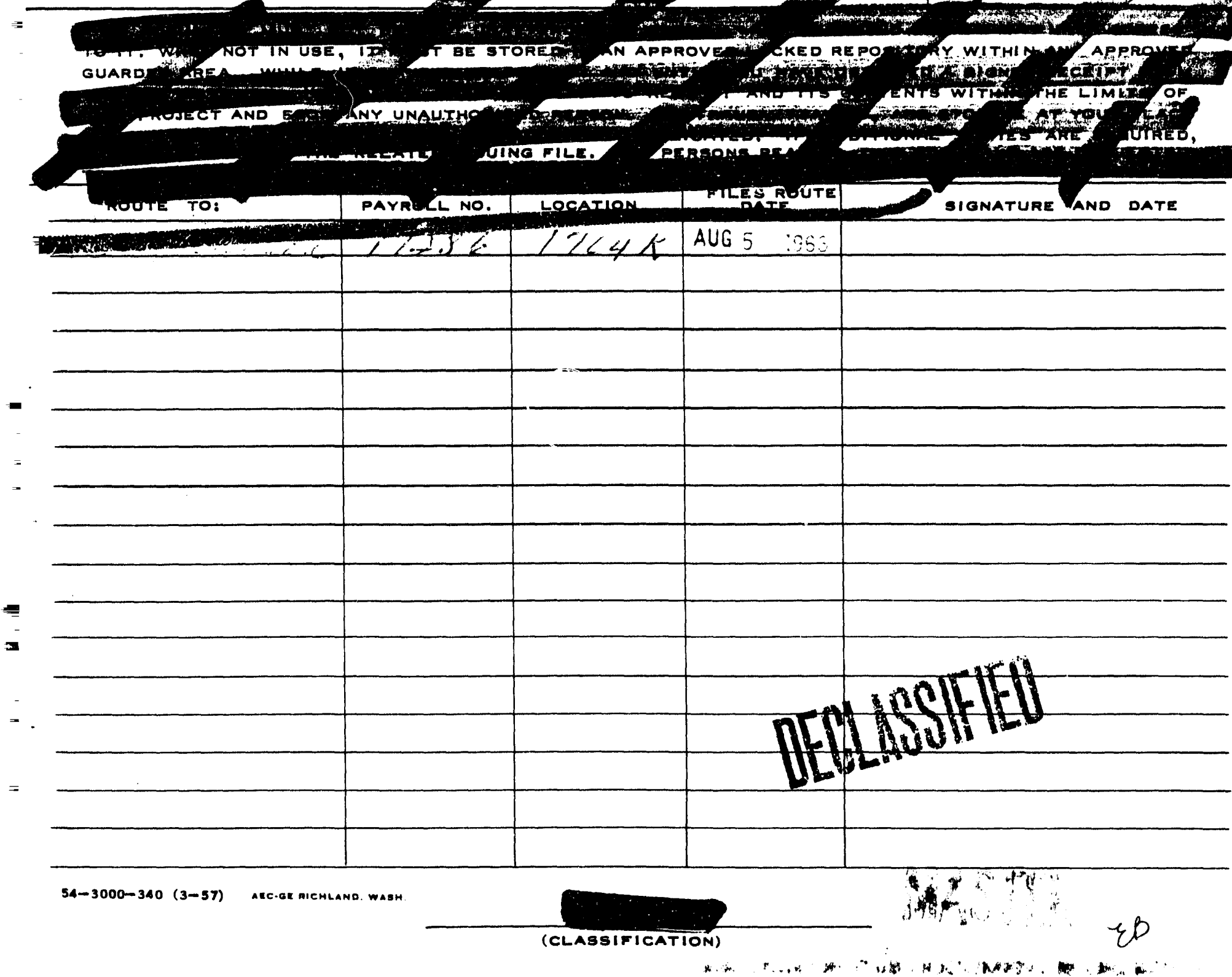

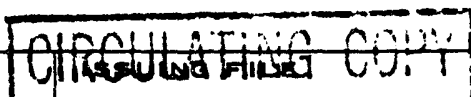
RECEIVED 1000 RIVEA

R. G. Geler
AUG 51933

RE, UTRN TO

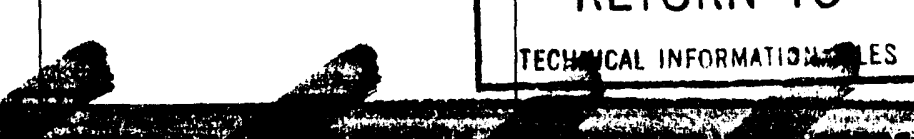

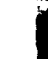




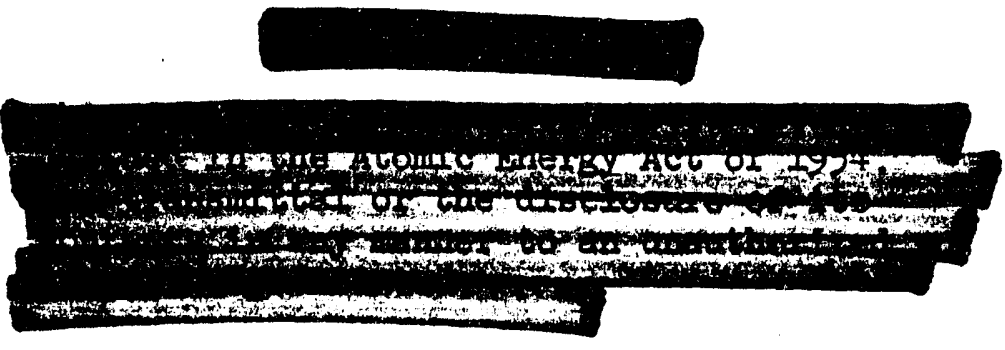

\section{INTERTM REPORT IV, PRODUCTION TEST IP-549-A HALF-PLANT LOW ALUM FEED WATER TREATMENT AT F REACTOR}

By

R. G. Geiar

Process and Reactor Development Subsection Research and Engineering Section

\section{TEELLASSTHET"}

By Authoity of $C C_{1}-P P_{-2}$ Rph $\tan 3-21-94$.

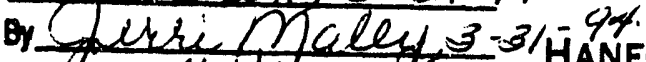

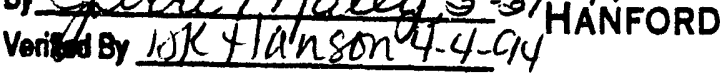

August 1, 1963

\section{ATOMIC PRODUCTS OPERATION RICHLAND. WASHINGTON}

\section{NOTICE}

This report was prepared for use within General Electric Company in the course of work under Atomic Energy Commission Contract AT(45.1) - 1350, and any views or opinions expressed in the report are those of the author only. This report is subject to revision upon collection of additional data.

\section{LEGAL NOTICE}

This report was prepared as an account of Government sponsored work. Neither the United States, nor the Commission, nor any person acting on behalf of the Commission:

A. Makes any warranty or representation, expressed or implied, with respect to the accuracy, com. pleteness, or usefulness of the information contained in this report, or that the use of any information, apparatus, method, or process disclosed in this report may not infringe privately owned rights; or

B. Assumes ary liabilities with respect to the use of, or for damages resulting from the use of any information, appuratus, method, or process disclosed in this report.

As used in the above, "person acting on behalf of the Commission" includes any employee or contractor of the Commission, or employee of such contractor, to the extent that such employee or contractor of the Commission, or employee of such contractor prepares, disseminates, or provides access to, any information pursuant to his employment or contract with the Commission, or his employment with such contractor.

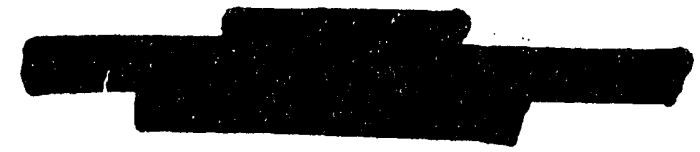




\section{DISTRIBUTION}

1. AIC-RLOO: Attn:

2. AEC-RLOO: Attn:

R. L. Plum

3. W. G. Albert

4. T. W. Ambrose

5. E. R. Astley

6. J. A. Ayres

7. J. W. Baker

8. R. R. Bloomstrand

9. M. A. Clinton

10. R. L. Dillon

11. $\therefore$ E. Fuller/C, G. Hough

12. K. G. Geier

13. O. H. Greager

14. A. B. Greninger

15. C. N. Gross

16. I. D. Gustafson

17. A. K. Hardin

18. K. L. Hladek

19. P. C. Jerman/W. N. Koop

20. M. P. Johnson

21. C. G. LewIs

22. A. J. Low

23. J. E. Morrissey

24. J. M. Nielsen

25. R. W. PItman

26. R. W. Reid

27. R. B. Richman

28. 0. C. Schroeder

29. W. B. Silker

30. H. G. Spencer

31. F. W. VanWormer

32. J. R. Young

33. Records Center

34. 300 Files 


\section{DECLLSSSFIED}

HW -76528 D

Page 3

\section{INTRODUCTION}

A half-plant low alum water treatment test (1) began at F Reactor on January 16, 1963. The test, which had been prompted by the analysis of ledge corrosion attack on fuel elements $\{2)$, will demonstrate whether or not high alum feed is responsible for in. creasing the frequency of ledge and groove(3) corrosion attack on fuel element surfaces. The effect will be evaluated by comparing visual examination results ortained from normal production fuel irradiated in process water treated with twc different alum feed rates. Three 20 column fuel discharges, ten from each side of: the reactor, have been taken during the test as follows:

1. One discharge prior to the start of the test(4).

2. One discharge such that the test side was exposed to coolant treated with both high and low alum feed $(5)$.

3. One discharge under test conditions $(6)$.

This report presents the results from the second discharge under test conditions. SUMMARY

The visual fuel element examination data from 673 F Reactor elements, 320 from the near side and 353 from the far side, which had been charged on March 29, 1963 and discharged on June 19, 1963, gerre the following results:

1. The over-all frequency of primary ledge corrosion was 12 per cent (2l per cent on the near side and three per cent on the far side).

2. The over-all frequency of primary groove corrosion was 0.7 per cent ( 1.6 per cent on the near side and none on the far side).

This is the first instance since the start of the test that a difference in the frequencies of localized corrosion was apparent between the two sides of the reactor. The high incidence of ledge corrosion on the near side (high alum) indicates that an alum effect may occur when other, presently unidentified, variables have combined to produce the proper threshold environment.,

\section{DISCUSSION}

\section{A. Water Treatment}

In order to determine whether high alum feed in the water treatment process was responsible for an increased frequency in the types of localized corrosion described as groove and ledge, the following half-plant test conditions were established at $F$ Reactor on January 16.

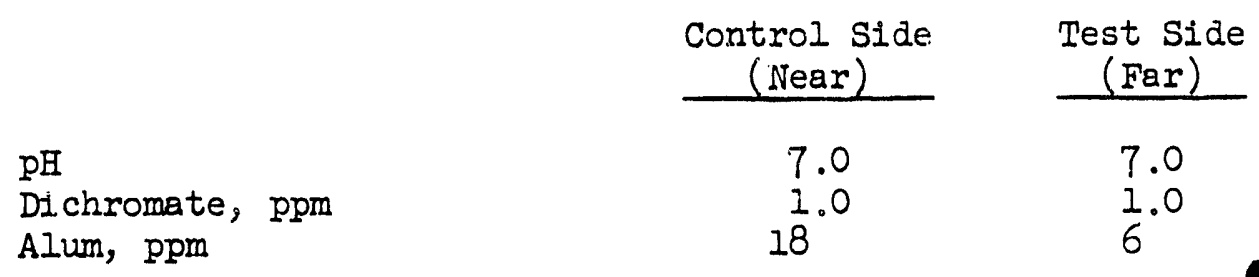


The actual alum feed rate used on the test side from the inception of the test to the end of June is shown in Figure 1 . On numerous occasions it was necessary to Increase the feed rate above $6 \mathrm{ppm}$ to produce coolant of acceptable quality. During the irradiation period of the fuel discussed in this report (March 29June 19), the alum feed rate to the test side averaged $10 \mathrm{ppm}$. Such a feed rate is considered satisfactorily below $18 \mathrm{ppm}$ to demonstrate alum effects, if any.

\section{B. Fuel Element Characteristics}

Twenty columns of fuel elements, ten from each side of the reactor, which had been charged during the outage of March 29, 1963, were discharged during the outage of June 19, 1963. The average irradiation conditions are shown in the following table.

\begin{tabular}{|c|c|c|}
\hline & $\begin{array}{l}\text { Control Side } \\
\text { (Near) } \\
\end{array}$ & $\begin{array}{c}\text { Test Side } \\
\text { (Far) }\end{array}$ \\
\hline Exposure, Mwd/t & 659 & 642 \\
\hline Tube Power, ITw & 1140 & 1110 \\
\hline Tube Inlet Temperature, ${ }^{\circ} \mathrm{C}$ & 10 & 1.0 \\
\hline Tubet outlet Temperature, ${ }^{\circ} \mathrm{C}$ & 101 & 99 \\
\hline Tube Flow, gpm & 47.6 & 47.5 \\
\hline Calendar Days in Reactor & 80 & 80 \\
\hline Operating Days & 69 & 69 \\
\hline Tube Age, Months & 15 & 13 \\
\hline Fuel Charge (with water mixer) & 31 pc OIIIN & $31 \mathrm{pe}$ OIIIN \\
\hline High Alum Feed Coolant & 69 & 0 \\
\hline Low Alum Feed Coolant & 0 & 69 \\
\hline
\end{tabular}

As has been the case with previous fuel discharges made during the production test, conditions on each side of the reactor were essentially identical.

For comparative purposes, the average irradiation conditions for all the fuel discharges made under the production test are given below,

\begin{tabular}{|c|c|c|c|c|}
\hline & $\begin{array}{l}\text { Pretest } \\
\text { Fuel }\end{array}$ & $\begin{array}{l}\text { First } \\
\text { Test }\end{array}$ & $\begin{array}{c}\text { Second } \\
\text { Test }\end{array}$ & Present \\
\hline Exposure, Mwa/t & 565 & 940 & $6+5$ & 650 \\
\hline Thube Power, KW & 1125 & 1140 & 1160 & 11.25 \\
\hline Tube outlet Temperature, ${ }^{\circ} \mathrm{C}$ & 102.5 & 98 & 98.5 & 100 \\
\hline Tube Inlet Temperature, ${ }^{\circ} \mathrm{C}$ & 14 & 7 & 7 & 10 \\
\hline Tube Flow, gpm & 48.2 & 47.6 & 47.8 & 47.6 \\
\hline Tube Age, Months & 9 & 11.5 & 12.5 & 14 \\
\hline Fuel Charge & 32 & $31+W M$ & $31+W M$ & $31+W M$ \\
\hline
\end{tabular}

While the first test fuel can be distingiished by its high exposure and the pretest fuel by the absence of water mixers, in general the irradiation variables have been held quite constant. 


\section{DECLLSSSFFED}

HW-76528 D

Page 5

C. Visual Fuel Element Examination

1. Definitions

Visual fuel element examination identifies the serious type of corrosion attack as well as recognizing the presence of secondary effects. While $a$ fuel element may exhibit several types of corrosion (pitting, uniform, ledge or groove), only primary and secondary are reported, according to the following definitions:

Primary - Type of corrosion considered most detrimental to fuel survival.

Secondary - Type of corrosion, although less important than primary, which may be a potential cause of future corrosion problems.

2. Results

Analysis of the visual examination data from 673 fuel elements, 320 from the near side and 353 from the far side, prodiced the results shown below

Localized Corrosion Frequency

\begin{tabular}{lrcc} 
& \multicolumn{3}{c}{ Per Cent of Pieces } \\
\cline { 2 - 4 } & Near & Far & Over-alI \\
Primary Ledge & 20.6 & 3.1 & 11.5 \\
Secondary Ledge & 1.2 & 0.0 & 0.6 \\
Primary Groove & 1.6 & 0.0 & 0.7 \\
Secondary Groove & 0.6 & 0.0 & 0.3 \\
Severe* $^{*}$ & 0.0 & 1.1 & 0.6
\end{tabular}

* Corrosion judged to be greater than ten mils deep.

The results from previous fuel discharges made prior to and under the production test are as follows:

Localized Dorrosion Frequency

\begin{tabular}{cccc}
\multicolumn{4}{c}{ Per Cent of Pleces } \\
\hline $\begin{array}{c}\text { PT-216 } \\
\text { Data }\end{array}$ & Pretest & Tirst & $\begin{array}{c}\text { Second } \\
\text { Test }\end{array}$ \\
Over-alI & Over-all & Over-all & Over-all
\end{tabular}

Primary Ledge

Secondary Ledge

Primary Groove Secondary Groove Severe*

10.5
4.5
6.2
3.5
4
15.7
4.3
8.4
8.4
9

8.0

1.2

0.5

1.9

2.5
1.4

0.0

0.2

0.2

1.9

* Corrosion judged to be greater than ten mils deep. 
It should be pointed out that in none of the previous data had there been a significant difference between the two sides of the reactor. Thus, it had been postulated that if high alum feed rates in the water treatment process contributed to an increased frequency of iedge or groove corrosion, the effect must be secondary to the effect of at least one other variabie. In all probability several other variables may be involved.

The 20 per cent incidence of ledge corrosion on the rear side (high alium) in the present fusl. as compared to only three per cent incidence or the far side ( Low alum) indicates that the unidentified variabies have hangec sufficientiy in the direction of increased corrosivity to permit an alum effect to be recognized. Also of significance is the continued absence. of groove corrosion. This tends to substantiate the theory that an environment more sorrosive than that required to produce ledge sorrosion is necessary to produce groove sorrosion.

In addition to identifying the most predominant types of corrosion, isuai. fuel element examination also delineates the location of the primary corrosion. The corrosion location data from the fuel duscharges made nder. the production test rave been analyzed, and the results are as follow:

\section{Location of Groove and Ledge Corrosion}

\begin{tabular}{|c|c|c|c|c|}
\hline & & Per $\mathrm{Ce}$ & Psece & \\
\hline & Pretest & $\begin{array}{l}\text { Flrst } \\
\text { Test } \\
\end{array}$ & $\begin{array}{l}\text { Second } \\
\text { Test } \\
\end{array}$ & Prasent \\
\hline Bottom & 28 & 69 & 100 & 76 \\
\hline Side & 13 & 8 & 0 & 1 \\
\hline Top & +8 & $2 ?$ & 0 & 4 \\
\hline Scat, ered. & 11 & 2 & 0 & 19 \\
\hline
\end{tabular}

It is of isterest to note that with the exception of the pressst fuel the groove and ledge corrosion occurred predominantly at the bottom. In the pretest fuel the groove and ledge corrosion oscurred predominantily at the top. Since the pretest fuel had been charged witrout watex mixers. It can be presumed that the mixers were resfonsible for the shift in location.

D. Effluent Activity

The average concentrations of $\mathrm{P}^{32}$ and $\mathrm{As} \mathrm{j}^{6}$ in the $\mathrm{F}$ Area effiuent from january 16 to Mey 31. are shown below.

$\begin{array}{lcc} & \mathrm{P}^{32} & \mathrm{As} \\ & \underline{\mathrm{pc} / \mathrm{ml}} & \mathrm{po} / \mathrm{ml} \\ \text { Test Side } & 11.7 & 134 \\ \text { Control Side } & 9.0 & 7 ! \\ \text { Old Reactor Average } & 7.1 & 7 \mathrm{i}\end{array}$


The results continue to show the test side $\mathrm{p}^{32}$ concentration to be 30 per ceat above the control side. Simliarly, the $A s{ }^{76}$ concentration in the test side effluent is about double the control side concentration. Sich resilts are trpical of what might be expected from using low alum feed. Inssmuch as the results have beer quite consistent for several. months, differentiation betweed reactor sides was terminated on May 31 .

E. Future Work

At startup after the June 19 outage, the sooiant pH was lowered to 6.6 and the sodium dichromate feed rate was increased to $1.8 \mathrm{ppm}$. In order to determine whether there is an alum effect at pH 6.6 as well as to continue monitomirig the status of ledge and groove corrosion, the present production test wIII ke continued for one year.

Ł

A supplement authorizing such action is alroulating for approval.

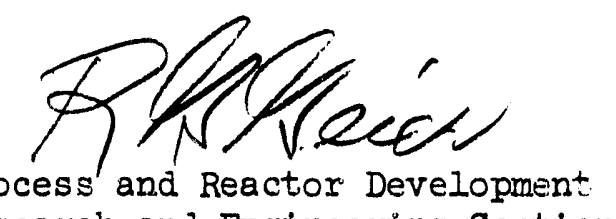

Research and Engineering Section

IRRADLATION PROCESSING DEPARTMENT:

RG Geier:nmd 


\section{DECLLSSIFIED}

EW-75528 D

Page 8

\section{REFERENCES}

(1) Clinton, M. A and $R, G$. Geler. Production Test IP-549-A, Half-Plant I, Alum Feed Water Treatment at F Reactor, HW-75541. November 8, 1962.

(2) Clinton, M. A. Analysis of the Frequency of Ledge Corrosion Attack Observed on Fuel Elements, $\mathrm{HW}-75368$. October 24, 1962 .

(3) Geier, R. G. An Analysis of the Frequency of Groove Corrosion Attack Observed on Fuel Elements. HW-77196. April 4, 1963.

(4) Geler, R. G. and M. A. Clinton. Interim Report I, Production Test IP-549-Ay Half-Plant Low Alum Feed Water Treatment at F Reactor, FW-76528. Febmiary 11, 1963.

(5) Geier, R. G. Interim Report II, Production Test IP-549-A, Half-Plant Low Alum Feed Water Treatment at $F$ Reactor, HW-76528 B. ApriI 26, 1963

(6) Geier, R。G. Interim Report III, Production Test IP-5'49-A, Ha.Lf-Plant Low AIjm Feed Water Treatment at F Reactor, HW-76528 C. June 11, 1963. 


\section{DECLLSSIFIE]}

HW-76528 D

Page 9

FIGURE 1

ALUM FEED RAIE - TEST HALF OF F REACTOR

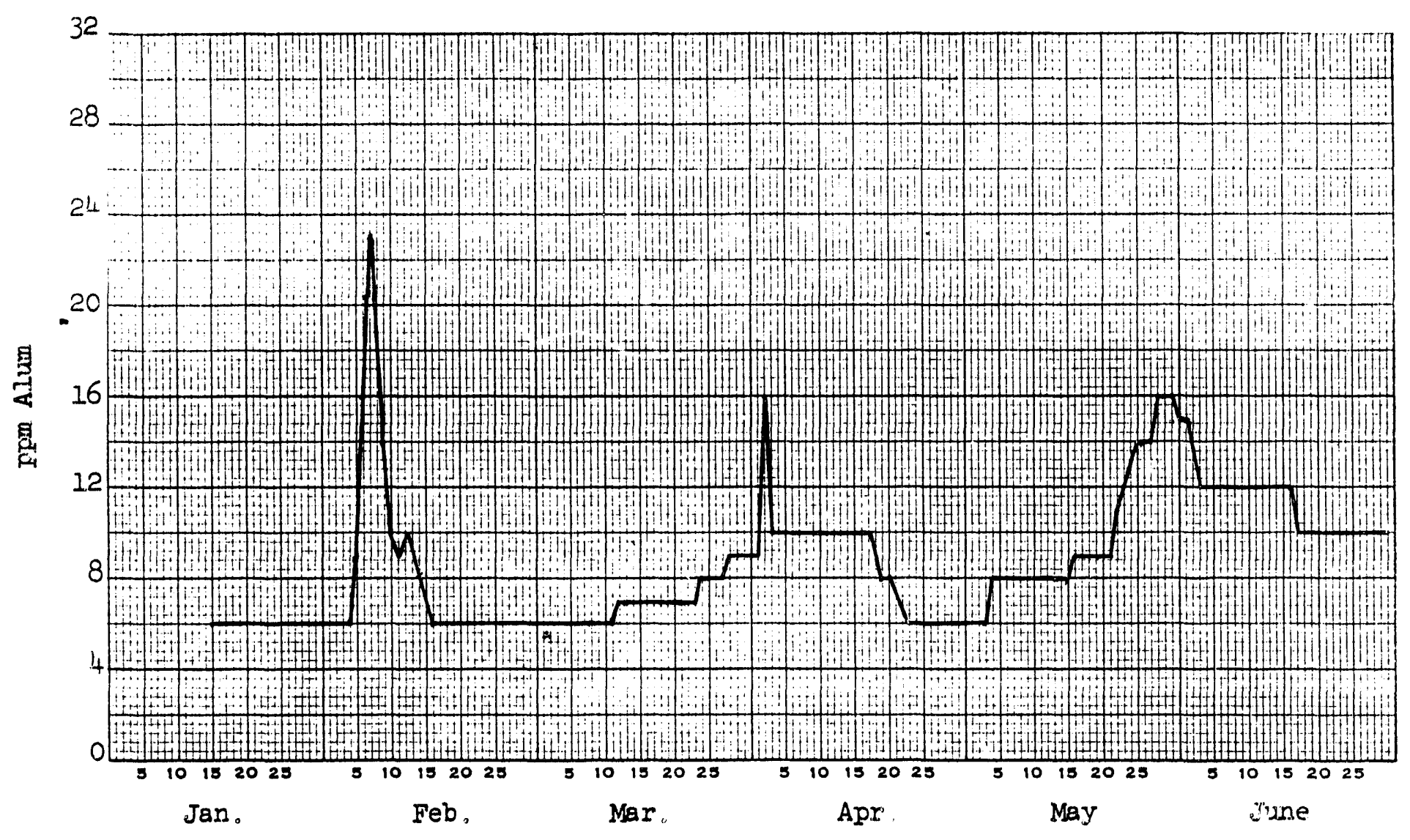



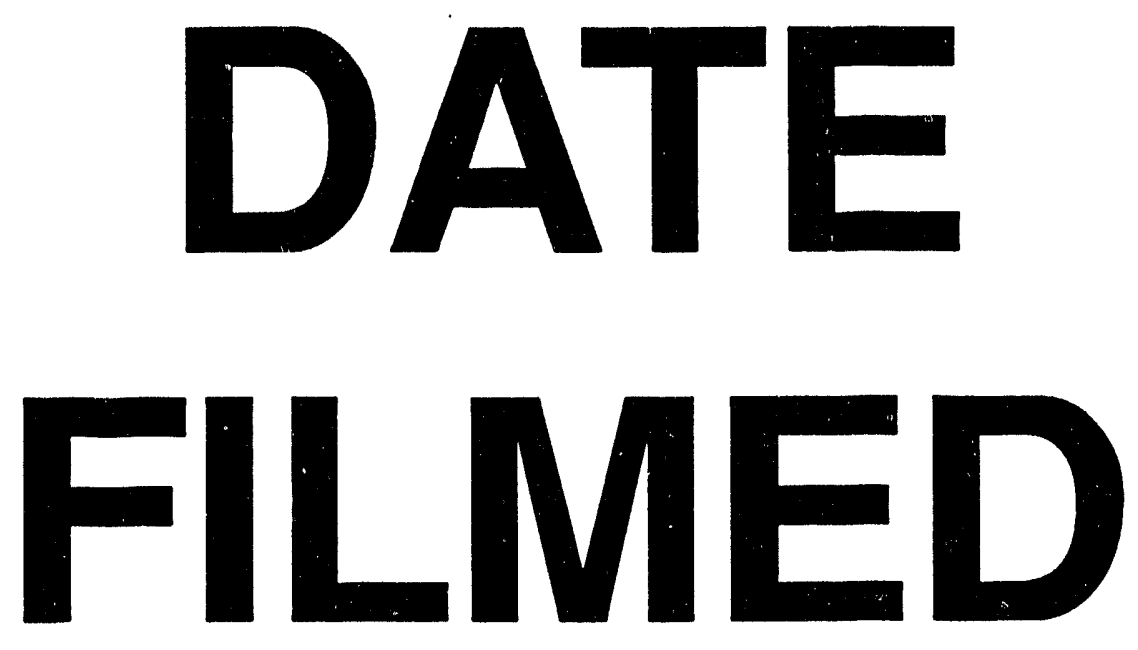

$9 / 29 / 94$
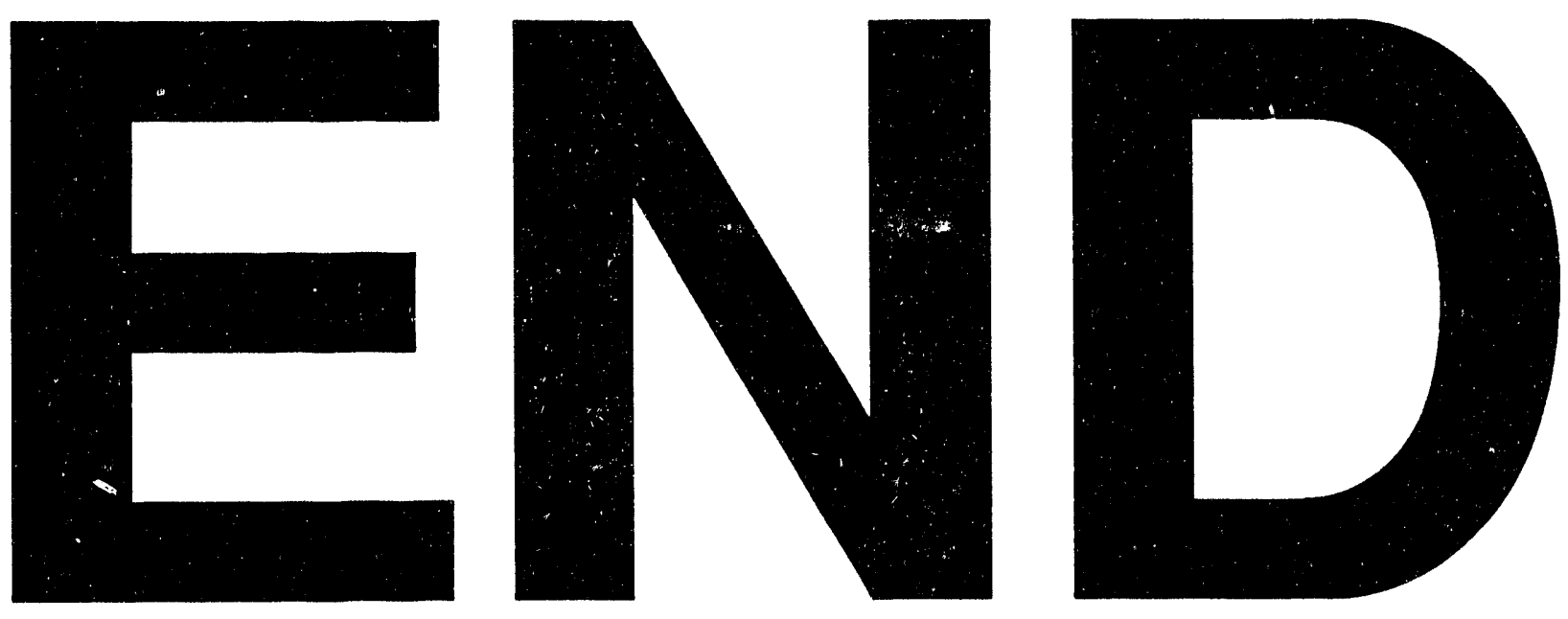